\title{
Possible Synergistic Action Between Carbamazepine and Lithium Carbonate in the Treatment of a Manic Patient.
}

John Matt Dorn, M.D.

Thomas Jefferson University Hospital

Follow this and additional works at: https://jdc.jefferson.edu/jeffjpsychiatry

Part of the Psychiatry Commons

Let us know how access to this document benefits you

\section{Recommended Citation}

Dorn, M.D., John Matt (1984) "Possible Synergistic Action Between Carbamazepine and Lithium Carbonate in the Treatment of a Manic Patient.," Jefferson Journal of Psychiatry. Vol. 2 : Iss. 1 , Article 8. DOI: https://doi.org/10.29046/JJP.002.1.004

Available at: https://jdc.jefferson.edu/jeffjpsychiatry/vol2/iss1/8

This Article is brought to you for free and open access by the Jefferson Digital Commons. The Jefferson Digital Commons is a service of Thomas Jefferson University's Center for Teaching and Learning (CTL). The Commons is a showcase for Jefferson books and journals, peer-reviewed scholarly publications, unique historical collections from the University archives, and teaching tools. The Jefferson Digital Commons allows researchers and interested readers anywhere in the world to learn about and keep up to date with Jefferson scholarship. This article has been accepted for inclusion in Jefferson Journal of Psychiatry by an authorized administrator of the Jefferson Digital Commons. For more information, please contact: JeffersonDigitalCommons@jefferson.edu. 


\title{
POSSIBLE SYNERGISTIC ACTION BETWEEN CARBAMAZEPINE AND LITHIUM CARBONATE IN THE TREATMENT OF A MANIC PATIENT
}

\author{
JOHN MATT DORN, M.D.
}

\section{Introduction}

Carbamazepine has been proven to be efficacious in some patients with affective disorders, notably those who have not responded well to lithium carbonate or neuroleptics $(1,2,3)$. For those who have responded poorly to either regimen, however, there have been no effective pharmacotherapies until recently, when case reports have suggested a possible synergistic action between lithium carbonate and carbamazepine $(4,5,6)$. The following case report supports this hypothesis.

\section{Case Report}

A 43-year-old man diagnosed by DSM-III criteria as having a bipolar disorder, manic type, was admitted to a psychiatric hospital, Coatesville VA Medical Center, for the fourth time in two years. Admission physical and laboratory results, as well as an EEG, were unremarkable. During previous admissions, this patient had remained unimproved despite adequate trials of a combination of lithium carbonate at plasma levels of 1.0-1.5 mEq/liter and high doses of various classes of neuroleptics. Again, on this admission, the patient was unchanged despite high doses of neuroleptics, including chlorpromazine at up to $2000 \mathrm{mg}$./day, and lithium carbonate at levels of 0.9-1.5 $\mathrm{mEq} /$ liter. On day eighteen carbamazepine was begun. Wihin four days the patient displayed marked reduction of psychomotor agitation, aggressiveness, and irritability, and on the twenty-second hospital day his chlorpromazine was discontinued. His improvement continued with abatement of manic symptoms. On the fifty-seventh hospital day, lithium carbonate was stopped to evaluate the patient's reponse to carbamazepine alone. His carbamazepine level, which ranged from $4.6-6.7 \mathrm{ug} / \mathrm{ml}$ (therapeutic range for seizure disorders: $3-12 \mathrm{ug} / \mathrm{ml}$ ), was then $6.7 \mathrm{ug} / \mathrm{ml}$. The patient displayed a gradual recrudescence of manic symptoms, including violent threats and insomnia, as well as the new complaint of bruxism. Following reinstitution of lithium carbonate on day seventy-seven, the patient's manic symptoms and his complaints of bruxism resolved within three days. He was discharged from the hospital without recurrence of his manic symptoms on the one-hundred-and-fifth hospital day. Four months after discharge, he remains euthymic.

Dr. Dorn is a third-year resident in Psychiatry. 


\section{Discussion}

This patient responded poorly to neuroleptics and lithium carbonate, but improved rapidly on a combination of carbamazepine and lithium carbonate. When an attempt was made to discontinue the lithium carbonate, the patient developed a recurrence of his manic symptoms that resolved when it was reinstituted. While it remains impossible to exclude a spontaneous remission, the temporal relationship between treatment and symptom response appears to support the hypothesis that this patient, while unresponsive to lithium carbonate and carbamazepine alone, responded to a synergistic effect of these drugs.

Elaboration of this proposed hypothesis awaits elucidation of the methods of action of the individual agents. Although a number of hypotheses exist $(2,7,8)$, their incipient nature make speculation about the mechanism of action of these agents' apparent synergism premature.

While this and other case reports suggest the usefulness of a combination of lithium carbonate and carbamazepine in otherwise treatment-resistant manic patients, its role as a treatment modality in affective disorders, including its potential risks (6), remain uncertainties that merit further study.

\section{REFERENCES}

1. Okuma, T, Kishimob, A, Inoue, K, et al: Anti-manic and prophylactic effects of carbamazepine (Tegretol) on manic-depressive psychosis. Folia Psychiatr Neurol Jpn 27: 283-297, 1973

2. Ballenger, JC, Post, RM: Carbamazepine in manic-depressive illness: a new treatment. Am J Psychiatry 137: 782-790, 1980

3. Neppe, VM: Carbamazepine in the psychiatric patient. Lancet 2: 334,1982

4. Lipinski, JF, Pope, HG: Possible synergistic action between carbamazepine and lithium carbonate in the treatment of three acutely manic patients. Am J Psychiatry 139: 948-949, 1982

5. Inoue, K, et al: A lithium and carbamazepine combination in the treatment of bipolar disorder-a preliminary report. Folia Psychiatr Neurol Jpn 35 (4): 465-475, 1981

6. Chaudhry, RP, Water, BGH: Lithium and carbamazepine interaction: possible neurotoxicity. J Clin Psychiatry 44: 30-31, 1983

7. Gerbino, L, Oleshansky, M, Gershon, S: Clinical use and mode of action of lithium, in Psychopharmacology: A Generation of Progress. Edited by Lipton MA, DiMascio A, Killam KF. New York, Raven Press, 1978

8. Post, R, Uhde, T, Putnam, F, Ballenge, J, Berrettini, W: Kindling and carbamazepine in affective illness. The Journal of Nervous and Mental Disease 170: 717-731, 1982 